\title{
Aksjologia zewnętrzna klauzul generalnych obowiązujących w polskim prawie podatkowym
}

\author{
The Extra-Legal Axiology of General Clauses Regulated in Polish Tax Law \\ Внешняя аксиология генеральных клаузул, действующих \\ в польском налоговом праве
}

\author{
MONIKA MÜNNICH \\ Dr hab., Katolicki Uniwersytet Lubelski Jana Pawła II \\ e-mail: mmunnich@kul.pl, https://orcid.org/0000-0002-9250-5748
}

\begin{abstract}
Streszczenie: Celem artykułu jest przedstawienie kryteriów pozaprawnych należących do obszaru aksjologii zewnętrznej, do których odsyłają w toku wykładni klauzule generalne unormowane w przepisach prawa podatkowego. Zasadność podejmowania tego typu badań wynika stąd, że od kilku lat ustawodawca coraz częściej w normach podatkowo-prawnych koduje różnorodne pod względem konstrukcyjnym klauzule generalne. Niestety zarówno przyczyny sięgania przez prawodawcę po te typowe jednak dla prawa prywatnego kategorie prawne, jak i sama treść uregulowanych w prawie podatkowym tego rodzaju zwrotów nieostrych nie zawsze jest uzasadniana w sposób racjonalny i przekonujący. Konsekwencją tego zjawiska są trudności związane z doprecyzowaniem w konkretnych stanach faktycznych właściwych wartości i norm pozaprawnych. W artykule wskazano, że unormowane w przepisach prawa podatkowego różnego rodzaju klauzule generalne niezależnie od ich rodzajów oscylują wokół ochrony dwóch generalnych różnych dóbr: publicznego i jednostkowego.
\end{abstract}

Słowa kluczowe: klauzule generalne, podatki, podatnik, wykładnia, system aksjologiczny

Summary: The aim of this article is to present non-legal criteria belonging to the area of extra-legal axiology, which refer to the course of interpretation of general clauses regulated in tax law. The legitimacy of undertaking the type of research results from the fact that for several years the legislator has more and more often encoded general clauses of various constructional terms in various types of tax and legal norms. Unfortunately, both the reasons for the legislator's use of these legal categories, which are typical for private law, and the very content of such fuzzy returns regulated in tax law, are not always rationally justified in a convincing manner. A consequence of this phenomenon are difficulties related to the specification of the appropriate values and non-legal standards in specific facts. The article shows that the various types of general clauses regulated in tax law, regardless of their types, oscillate around the protection of two general different goods: public and individual.

Key words: general clause, taxes, taxpayer, interpretation, axiological system

Резюме: Цель данной статьи - представить неюридические критерии, относящиеся к сфере внешней аксиологии, к которым в процессе толкования отсылают генеральные клаузулы, нормированные в налоговом законодательстве. Правомерность такого рода исследований обусловлена тем, что на протяжении нескольких лет законодатель все чаще фиксирует в налогово-правовых нормах различные по конструкции генеральные клаузулы. К сожалению, как причины использования законодателем этих правовых категорий, характерных для частного права, так и содержание таких неточных формулировок, регламентированных в налоговом законодательстве, не всегда обоснованы рационально и убедительно. В следствие этого явления появляются трудности с определением соответствующих ценностей и внеправовых норм в конкретных ситуациях. В статье указывается, что различные виды генеральных клаузул в налоговом законодательстве, независимо от их типов, колеблются вокруг защиты двух различных общих благ: общественного и индивидуального.

Ключевые слова: генеральные клаузулы, налогообложение, налогоплательщик, толкование, аксиологическая система 


\section{Wstęp}

Klauzule generalne od kilku dziesięcioleci stanowią niezwykle ważną kategorię prawną przenikającą cały system prawa prywatnego i publicznego ${ }^{1}$. Głównym celem ich kodowania w przepisach prawa jest zawsze ochrona konkretnego dobra lub interesu. Zgodnie z zasadami wykładni prawa tego rodzaju zwroty ocenne podlegają z reguły wykładni funkcjonalnej, w toku której interpretator zobowiązany jest do doprecyzowania zakresu znaczeniowego danej klauzuli poprzez uwzględnienie wartości pozaprawnych, do których ta klauzula odsyła ${ }^{2}$. Specyfika klauzul generalnych polega zatem na tym, że są kategoriami prawnymi łączącymi normy prawa pozytywnego, w których są zakodowane z systemem pozaprawnym należącym do obszaru aksjologii zewnętrznej. W tym typie aksjologii mieszczą się nie tylko pozaprawne kryteria moralne, ale również polityczne, gospodarcze i społeczne ${ }^{3}$.

Warunkiem skuteczności oddziaływania danej klauzuli generalnej jest jej właściwa konstrukcja językowa. Jeżeli klauzula jest źle sformułowana, np. zawiera zbyt wiele określeń nieostrych, niemożliwa staje się jej prawidłowa interpretacja, gdyż interpretator może mieć trudności z doprecyzowaniem kryteriów pozaprawnych, w oparciu o które mógłby jednoznacznie w odniesieniu do konkretnego stanu faktycznego dookreślić jej zakres znaczeniowy.

Celem niniejszego artykułu jest przedstawienie płaszczyzny aksjologicznej klauzul generalnych funkcjonujących w przepisach prawa podatkowego. Uzasadnieniem dla tego typu badań jest fakt, iż od kilku lat coraz częściej w różnych rodzajach norm podatkowo-prawnych kodowane są różnorodne pod względem konstrukcyjnym klauzule generalne. Pomimo że liczne wątpliwości budzi szata językowa

1 Zob. A. Stelmachowski, Wstęp do teorii prawa cywilnego, Warszawa 1969, s. 290-291.

2 Por. S. Grzybowski, Struktura i treść przepisów prawa cywilnego odsyłajacych do zasad współżycia społecznego, Studia Cywilistyczne 1965, t. 6, s. 25-26 i 33. W piśmiennictwie spotkać można nowe spojrzenia na charakter klauzul generalnych jako kategorii prawnych odsyłających do regulacji wewnątrz systemowych, por. M. Wilejczyk, Integralna filozofia prawa Ronalda Dworkina a problem klauzul generalnych. Klauzule generalne jako odesłania wewnątrz systemowe, Państwo i Prawo 2019, nr 2, s. 3-15.

3 Zob. S. Grzybowski, Struktura i treść przepisów prawa cywilnego..., s. 38; K. Wójcik, Z problematyki klauzul generalnych prawa cywilnego, Studia Prawno-Ekonomiczne 1982, t. 27, s. 91; M. Safjan, Klauzule generalne w prawie cywilnym. Przyczynek do dyskusji, Państwo i Prawo 1990, nr 11, s. 55; L. Leszczyński, Właściwości posługiwania się klauzulami generalnymi w prawie polskim. Perspektywa zmian trendu, Kwartalnik Prawa Publicznego 1995, z. 3, s. 296-298; A. Hanusz, Klauzule generalne w ordynacji podatkowej, Państwo i Prawo, 2016, nr 8, s. 5-6; P. Borszowski, Ważny interes podatnika w regulacji ulg w spłacie zobowiązań podatkowych, LEX nr 180045, s. 71-72; M. Kordela, Aksjologiczna wykładnia prawa, Acta Universitatis Wratislaviensis. Przegląd Prawa i Administracji 2017, t. 110, s. $153,158$. 
niektórych klauzul generalnych zawartych w przepisach podatkowych oraz nie zawsze racjonalne i przekonujące są przesłanki ich kodowania w treści norm prawno-podatkowych, to bez wątpienia są to takie kategorie prawne, które zapewniają ochronę dwóm różnym i równym sobie dobrom: publicznemu i jednostkowemu.

\section{Klauzule generalne chroniące interes publiczny oraz bezpieczeństwo i porządek państwa}

Najliczniej w przepisach prawa podatkowego unormowane są tradycyjne klauzule generalne chroniące interes publiczny i ważny interes podatnika. Do pierwszego rodzaju klauzul należą:

1) interes Skarbu Państwa

2) ważny interes państwa ${ }^{5}$;

3) interes publiczny/ważny interes publiczny (ordynacja podatkowa) ${ }^{6}$ oraz ważny interes publiczny (podatek akcyzowy) ${ }^{7}$; interes publiczny (ustawa o grach hazardowych) ${ }^{8}$.

4 Zob. art. 1 ust. 2 ustawy z dnia 16 listopada 2016 r., o Krajowej Administracji Skarbowej, tekst jednolity: Dz. U. z 2020 r. poz. 505 z późn. zm. (dalej: ustawa o KAS). W myśl powołanych przepisów klauzula interesów Skarbu Państwa stanowi jedną z przesłanek szerokiego zakresu zadań, w jaki wyposażone zostały w tej ustawie organy KAS, czyli wyspecjalizowana administracja rządowa wykonująca zadania z zakresu szeroko w ustawie rozumianej ochronie finansów publicznych.

5 Zob. art. 119 ust. 1 pkt 1 ustawy z dnia 6 grudnia 2008 r. o podatku akcyzowym, tekst jednolity: Dz. U. z 2020 r. poz. 722 z późn. zm. (dalej: u.p.a.). Z przepisów wynika, że minister finansów może w oparciu o tę klauzulę w drodze rozporządzenia zwolnić z obowiązku oznaczania niektórych wyrobów akcyzowych znakami akcyzy.

6 Zob. art. 20; art. $22 \S 1$; art. $48 \$ 1$; art. 67a; art. 160; art. $169 \$ 3$ pkt 1; art. $179 \$ 1$; art. $208 \S 2$; art. 234; art. $240 \$ 2$; art. $253 \$ 1$; art. $253 \mathrm{a} \$ 1$; art. 270 ; art. 299b $\$ 2$ ustawy z dnia 29 sierpnia 1997 r. - Ordynacja podatkowa, tekst jednolity: Dz. U. z 2020 r. poz. 1325 z późn. zm. (dalej: o.p.). Podkreślić należy, że w powołanych przepisach ustawodawca zakodował klauzulę chroniącą interes publiczny zarówno w przepisach materialnych, jak i w przepisach procesowych.

7 Zob. art. 52 ust. 1 pkt 2 u.p.a. Zgodnie z treścią przepisów właściwy naczelnik urzędu skarbowego odmawia wydania zezwolenia na prowadzenie składu podatkowego, w przypadku gdy wydanie zezwolenia może powodować zagrożenie ważnego interesu publicznego.

8 Zob. art. 33 ust. 4 u.g.h. W przypadku okoliczności wskazujących na zaistnienie rażącego naruszenia prawa, minister finansów w oparciu o zakodowaną w powołanych przepisach klauzulę generalną interesu publicznego unieważnia przetarg w drodze decyzji. Przetarg minister ogłasza w sytuacji, gdy o koncesję na prowadzenia kasyna albo zezwolenie na prowadzenie salonu gry bingo pieniężne oraz zezwolenia na urządzanie zakładów wzajemnych, których wydanie podlega ograniczeniom ilościowym, ubiega się więcej niż jeden podmiot spełniający warunki określone w ustawie. 
Wymienione klauzule generalne pomimo że różnią się nieco szatą językową, to pod względem merytorycznym chronią w zasadzie to samo dobro i wartości należące do obszaru państwa, czy też szerzej publicznego. Zróżnicowanie językowe powołanych wyżej zwrotów nieostrych ocennych ściśle związane jest z tym, w jakiego typu przepisach podatkowych są one zakodowane ${ }^{9}$.

Powołane wyżej przepisy ustawy o podatku akcyzowym oraz ustawy o grach hazardowych normują kwestie dotyczące władztwa państwa w zakresie udzielania koncesji i zezwoleń dotyczących prowadzenia różnych rodzajów działalności gospodarczej. W przypadku podatku akcyzowego jest to skład podatkowy, a w przypadku podatku od gier, działalności gospodarczej dotyczącej organizowania gier i zakładów wzajemnych. Obydwa rodzaje opodatkowanej działalności z uwagi na jej charakter podlegają ścisłej reglamentacji prawnej, która ze swej istoty stanowi ochronę interesów finansowych i ekonomicznych państwa. Szczególne znaczenie ma w tym kontekście klauzula generalna interesu publicznego zawarta w ustawie o grach hazardowych. Restrykcyjne przepisy zawarte w tej ustawie stały się bowiem przedmiotem orzeczenia Trybunału Konstytucyjnego (dalej: TK). Wyrok został wydany na wniosek złożony przez Naczelny Sąd Administracyjny (dalej: NSA) i Sąd Rejonowy w Gdańsku w związku z wątpliwościami dotyczącymi tego, czy wprowadzony przez ustawę zakaz stawiania automatów do gier poza kasynami nie narusza konstytucyjnej zasady wolności gospodarczej. TK nie tylko nie podzielił tych wątpliwości, ale uznał, że ustawa o grach hazardowych została uchwalona bez naruszenia konstytucyjnego trybu ustawodawczego, a organizowanie gier na automatach wyłącznie w kasynach gry spełnia wymogi ważnego interesu publicznego, uzasadniające ograniczenie wolności działalności gospodarczej. TK stwierdził również, że ograniczenie możliwości organizowania gier na „jednorękich bandytach” wyłącznie do kasyn spełnia konstytucyjne wymogi ograniczenia swobody gospodarczej, albowiem jest niezbędne dla ochrony społeczeństwa przed negatywnymi skutkami hazardu oraz dla zwiększenia kontroli państwa nad tą sferą, stwarzającą liczne zagrożenia nie tylko w postaci uzależnień, ale także struktur przestępczych, których zwalczanie leży w interesie publicznym ${ }^{10}$. Z tych względów właściwe organy podatkowe $\mathrm{w}$ toku stosowania przepisów podatkowych, normujących ważny interes państwa lub interes publiczny, interpretują te klauzule w ten sposób, że ich zakres znaczeniowy wypełniają wartościami stricte związanymi z interesem ekonomicznym lub fiskalnym państwa. W ustawach normujących wskazane wyżej

9 Szerzej na temat klasyfikacji klauzul generalnych jako zwrotów nieostrych zob. M. Münnich, Nieostre zwroty ocenne w polskim prawie podatkowym, Lublin 2017, s. 30-45.

Zob. wyrok TK z dnia 11 marca 2015 r., P/14, Dz. U. z 2015 r. poz. 369. 
podatki nie ma bowiem przepisów zobowiązujących podmioty dokonujące interpretacji do uwzględniania równorzędnego im interesu podatnika.

Taki kierunek interpretacji klauzul generalnych dotyczących interesu publicznego jest niedopuszczalny w toku wykładni przepisów normujących tę samą klauzulę interesu publicznego w ordynacji podatkowej. W ustawie tej klauzula interesu publicznego występuje bowiem $\mathrm{z}$ reguły $\mathrm{w}$ tych samych przepisach materialnych i procesowych, w których unormowany jest ważny interes podatnika lub ważny interes strony. Takie usytuowanie klauzul sprawia, że zarówno interes publiczny, jak i ważny interes publiczny, tak w judykaturze, interpretacjach podatkowych, jak w piśmiennictwie, powszechnie traktowane są jako dyrektywy postępowania, nakazujące podmiotom stosującym prawo respektowanie wartości wspólnych dla całego społeczeństwa lub danej społeczności lokalnej, takich jak: sprawiedliwość, bezpieczeństwo, równość, zaufanie obywateli do organów władzy publicznej, sprawność działania aparatu państwowego itp. ${ }^{11}$

Niestety w praktyce podatkowej zdarza się, że zawarte w przepisach materialnych ordynacji klauzule generalne chroniące interes publiczny organy podatkowe utożsamiają z interesem fiskalnym. Przy czym interes ten bywa rozumiany dychotomicznie. Po pierwsze jako element polityki fiskalnej, której celem jest zapewnienie właściwych mechanizmów zabezpieczających dopływ odpowiedniego poziomu należności podatkowych do budżetu podmiotu prawa publicznego ${ }^{12}$. Po drugie jako zakaz kreowania przez organy podatkowe zbędnych wydatków, takich jak np. na zasiłki dla bezrobotnych czy pomoc opieki społecznej ${ }^{13}$. Interes publiczny może być bowiem uzasadniony również wówczas, gdy zapłata zaległości podatkowych spowoduje konieczność sięgania przez podatnika do środków pomocy państwa, gdyż nie będzie w stanie zaspakajać swoich potrzeb materialnych ${ }^{14}$.

11 Zob. wyrok WSA w Warszawie z dnia 8 stycznia 2007 r., III SA/Wa 2904/2006, Monitor Podatkowy 2007, nr 11, s. 43-45; wyrok WSA w Rzeszowie z dnia 27 maja 2010 r., I SA/Rz 210/10, CBOSA; wyrok WSA w Białymstoku z dnia 6 lipca 2010 r., I SA/Bk 156/10, LEX nr 590320; wyrok WSA w Opolu z dnia 8 lutego 2012 r., SA/Op 507/11, LEX nr 1116042; wyrok NSA z dnia 11 czerwca 2015 r., I SA/ Kr 274/15, CBOSA.

12 W ramach tak pojętego interesu publicznego mieści się realizacja zadań publicznych, takich jak: zapewnienie opieki i pomocy osobom niepełnosprawnym, świadczenie usług w obszarze edukacji, służby zdrowia, infrastruktury technicznej. Zob. wyrok NSA z dnia 16 stycznia 2007 r., I FSK 477/06, ONSAiWSA 2008, nr 2 (23), poz. 32; wyrok NSA z dnia 18 lutego 2016 r., II FSK 1569/08, CBOSA oraz B. Dauter, Komentarz do art. 67, w: S. Babiarz i in., Ordynacja podatkowa. Komentarz, Warszawa 2009, s. 286.

13 Zob. wyrok NSA z dnia 24 maja 2000 r., III SA 1087/99, cyt. za: B. Gruszczyński, w: S. Babiarz i in., Ordynacja podatkowa..., s. 200; wyrok NSA z dnia 30 maja 2001 r., III SA 830/00, CBOSA oraz wyrok NSA z dnia 31 października 2000 r., III SA 660/99, CBOSA.

Zob. wyrok NSA z dnia 22 kwietnia 1999 r., SA/Sz 850/98, CBOSA. 
Na gruncie przepisów procesowych natomiast ważny interes publiczny stanowi z kolei przesłankę uzasadniającą m.in.: uchylenie lub zmianę decyzji ostatecznej zarówno w sytuacji, gdy strona nie nabyła jeszcze prawa ${ }^{15}$, jak i w przypadku, gdy strona prawo takie już nabyła ${ }^{16}$.

$\mathrm{W}$ orzecznictwie podkreśla się, że klauzula generalna interesu publicznego powinna być interpretowana nie tylko w świetle norm konstytucyjnych dotyczących obowiązków podatkowych ${ }^{17}$, ale również z uwzględnieniem praw i wolności konstytucyjnych, obowiązujących w demokratycznym państwie prawa, które mogą znaleźć odniesienie do stanu faktycznego rozpatrywanej sprawy ${ }^{18}$.

W prawie podatkowym coraz częściej omówione wyżej tradycyjne klauzule generalne chroniące interes państwa lub interes publiczny zestawia się z klauzulami o proweniencji administracyjnej dotyczącymi ochrony bezpieczeństwa państwa i porządku publicznego. W konsekwencji powstają następujące twory prawne, zawierające podwójne lub potrójne klauzule generalne wymagające $\mathrm{z}$ uwagi na semantykę np. użycie spójników jednoczesnej interpretacji w odniesieniu do danego stanu faktycznego:

1) ważny interes związany $z$ bezpieczeństwem publicznym, obronnością państwa, bezpieczeństwem paliwowym państwa lub ochroną środowiska ${ }^{19}$;

2) bezpieczeństwa publiczne, ważny interes ekonomiczny lub finansowy Rzeczypospolitej Polskiej lub Unii Europejskiej ${ }^{20}$;

3) bezpieczeństwo państwa, porządek publiczny lub bezpieczeństwo interesów ekonomicznych państwa ${ }^{21}$.

15 Zob. art. 253 o.p.

16 Zob. art. 253a o.p. Mowa jest tu oczywiście o prawach w sferze materialnej, a nie procesowej, takich jak np. odroczenie terminu płatności podatku lub zaległości podatkowej, stwierdzenie nadpłaty, zob. J. Brolik, Komentarz do art. 253, w: J. Brolik i in. Ordynacja podatkowa. Komentarz, 2013 [baza danych LEX].

17 Zob. art. 84 i 217 Konstytucji Rzeczypospolitej Polskiej z dnia 2 kwietnia 1997 r., Dz. U. Nr 78, poz. 483 (dalej: Konstytucja RP).

18 Zob. np. art. 67 ust. 2 czy art. 71 ust. 1 Konstytucji RP oraz wyrok NSA z dnia 3 lipca 2007 r., I FSK 594/06, CBOSA.

19 Klauzule te stanowią przesłanki udzielenia przez ministra finansów zwolnień w podatku akcyzowym, zob. art. 39 ust. 1 pkt 1 u.p.a.

20 Zob. art. 47 ust. 1 pkt 1 ustawy o KAS.

21 Zob. art. 11 ust. 1 pkt 1 i ust. 2 oraz art. 28 ust. 3 pkt 3 ustawy $z$ dnia 19 listopada 2009 r. o grach hazardowych, tekst jednolity: Dz. U. z 2019 r. poz. 847 z późn. zm. (dalej: u.g.h.). 
Jedną z najbardziej oryginalnych klauzul generalnych tego typu jest unormowana tylko w jednym akcie prawnym klauzula - porządek publiczny Rzeczypospolitej Polskiej ${ }^{22}$.

Podkreślić należy, że prawodawca sięga po ten rodzaj klauzul coraz częściej w dwóch przypadkach. Pierwszy dotyczy norm ustrojowych regulujących organizację i zakres działań organów KAS. Klauzule unormowane w tego typu aktach prawnych stanowią przesłankę uzasadniającą szeroki zakres zadań i kompetencji organów KAS. Podobną funkcję pełnią klauzule generalne chroniące bezpieczeństwo i porządek państwa, zawarte w ustawie o grach hazardowych lub podatku akcyzowym. Są one obok interesu publicznego czy ekonomicznego państwa dodatkowymi przesłankami umożliwiającymi organom podatkowym wykonywanie ich uprawnień wobec podatników, np. w zakresie udzielania zwolnień akcyzowych lub niewyrażenia zgody na udzielenie koncesji na prowadzenie działalności gospodarczej w zakresie organizacji gier i zakładów wzajemnych. Reasumując, stwierdzić należy, że ten typ klauzul stosowany jest bardzo rzadko, a ich zasadniczym celem jest zapewnienie bezpieczeństwa i pewności obrotu prawa podatkowego.

\section{Klauzule generalne chroniące ważny interes jednostki}

Klauzule generalne, chroniące ważny interes jednostki, występują w prawie podatkowym znacznie rzadziej aniżeli te chroniące interes publiczny. Do klauzul tego typu należą:

1) ważny interes podatnika $a^{23}$

2) ważny interes strony ${ }^{24}$;

3) ważny interes adresata ${ }^{25}$,

4) ważny interes osoby obowiązanej ${ }^{26}$.

Jak wspomniano wyżej, ważny interes podatnika oraz ważny interes strony są $\mathrm{z}$ reguły zamieszczane $\mathrm{w}$ tych samych przepisach, w których unormowana jest

22 Zob. art. 13 pkt 5 ustawy $\mathrm{z}$ dnia $\mathrm{z}$ dnia 9 marca $2017 \mathrm{r}$. o wymianie informacji podatkowych $\mathrm{z}$ innymi państwami, tekst jednolity: Dz. U. z 2020 r. poz. 343 z późn. zm.

23 Zob. art. $22 \$ 1$; art. $22 \$ 2$ pkt 1 ; art. $48 \$ 1$; art. 67 a; art. $77 a ; 253 \$ 1$ o.p. oraz art. 22 ust. 2 ustawy z dnia z dnia 29 sierpnia 1997 r. - Ordynacja podatkowa, tekst jednolity: Dz. U. z 2020 r. poz. 1325 z późn. zm. (dalej: o.p.).

24 Zob. art. 20; art. $169 \$ 3$ pkt 1; art. 253a §1 o.p.

25 Zob. art. $160 \$ 1$ o.p.

26 Art. $270 \$ 1$ o.p. 
klauzula generalna interesu publicznego. Obydwa zwroty nieostre, chroniące interes jednostkowy i publiczny, połączone są w tych przepisach spójnikiem „lub”, gdyż stanowią one rozłączne przesłanki udzielenia przez organy podatkowe ulg i zwolnień podatkowych. Odkodowanie choćby jednej klauzuli w odniesieniu do danego stanu faktycznego zobowiązuje organ podatkowy do rozpatrzenia danej sprawy w granicach uznania administracyjnego i może przyczynić się do pozytywnego rozstrzygnięcia postępowania w sprawie udzielenia ulgi podatkowej. Ponadto zastosowanie spójnika „lub” oznacza, że z punktu widzenia legislatora obydwie klauzule chronią równorzędne prawnie wartości ${ }^{27}$. Tezę tę potwierdza jednolite w tej kwestii orzecznictwo sądów administracyjnych ${ }^{28}$, $\mathrm{TK}^{29}$ oraz nauki prawa podatkowego ${ }^{30}$.

Wartości pozaprawne, do których odsyła klauzula generalna ważnego interesu podatnika, można sklasyfikować w cztery grupy. Pierwsza obejmuje ocenę zaistniałych obiektywnie trudnych sytuacji życiowych, rodzinnych i osobistych, w jakich znalazł się podatnik ubiegający się o ulgę podatkową na sutek zaistnienia nadzwyczajnych zdarzeń losowych, takich jak: pożar, klęska urodzaju, choroba, wychowywanie niepełnosprawnego dziecka, utrata możliwości zarobkowania, utrata losowa majątku ${ }^{31}$. Do drugiej grupy należą okoliczności dotyczące stricte ekonomicznej i majątkowej sytuacji podatnika występującego $\mathrm{z}$ wnioskiem o konkretną ulgę

27 Zob. J. Szczupakowski, Kontrowersje wokół „wyważenia” ważnego interesu podatnika z interesem publicznym, w: Stanowienie stosowanie prawa podatkowego w Polsce. Ocena i kierunki zmian, red. B. Kucia-Guściora, M. Münnich, A. Zdunek, R. Zieliński, Lublin 2017, s. 239-248; A. Hanusz, Klauzule generalne $w$ ordynacji podatkowej..., s. 7.

28 Zob. m.in. wyrok NSA z dnia 2 sierpnia 2000 r., III SA 2178/99, Gazeta Prawna 2006, nr 227, s. 12; wyrok NSA z dnia 8 października 2002 r., SA/Wr 1458/01, POP 2004, z. 3, poz. 59; wyrok WSA w Warszawie z dnia 20 marca 2007 r., III SA/Wa 1205/06, LEX nr 329215; wyrok NSA z dnia 18 lutego 2010 r., II FSK 1569/08, CBOSA; wyrok WSA w Lublinie z dnia 8 stycznia 2012 r., I SA/Lu 712/11, LEX nr 1110138.

29 Relacja obydwóch interesów indywidualnego i publicznego w kontekście zasady proporcjonalności w prawie publicznym stała się przedmiotem kilkudziesięciu orzeczeń TK. Ich wykaz za lata 1993-2009 zob. Zasada proporcjonalności ( $w$ odniesieniu do prawa publicznego) w tezach Trybunału Konstytucyjnego, Biuro Trybunału Konstytucyjnego Zespół Orzecznictwa i Studiów, Warszawa 2009, http://trybunal.gov.pl/fileadmin/content/dokumenty/Zestawienie_tez_dotyczacych_zasady_ proporcjonalnosci_w_zakresie_pawa_publicznego.pdf [dostęp: 5.12 .2020 r.].

30 Por. B. Dauter, Komentarz do art. 67..., s. 286, 359; B. Gruszczyński, w: S. Babiarz i in., Ordynacja podatkowa..., s. 869; J. Borkowski, Komentarz do art. 253, w: B. Adamiak, J. Borkowski, R. Mastalski, J. Zubrzycki, Ordynacja podatkowa. Komentarz 2012, Wrocław 2012, s. 1066.

31 Por. wyrok NSA z dnia 22 kwietnia 1999 r., SA/Sz 850/98, niepublikowany; wyrok NSA z dnia 16 stycznia 2003 r., SA/Sz 945/01, CBOSA; wyrok NSA z dnia 8 lutego 2010 r., II FSK 1569/08, CBOSA; wyrok WSA w Łodzi z dnia 19 maja 2011 r., I SA/Łd 148/11, CBOSA. Zob. także: P. Borszowski, Ważny interes podatnika...; R. Zenc, Ważny interes podatnika" przy udzielaniu ulg w spłacie zobowiąań podatkowych, Prawo Pomocy Publicznej 2014, nr 4, s. 13. 
podatkową. W tym przypadku klauzula generalna ważny interes podatnika odsyła do dokonania oceny w oparciu o kryteria pozaprawne takich informacji jak wysokość uzyskiwanych przez podatnika dochodów oraz przeznaczenia dokonywanych wydatków, ze szczególnym uwzględnieniem wydatków ponoszonych w związku z ochroną zdrowia własnego lub członków najbliższej rodziny (koszty leczenia) ${ }^{32}$. W obydwóch przypadkach niezwykle istotne w ustalaniu zaistnienia ważnego interesu podatnika jest wykazanie przez niego braku winy w utracie zdolności płatniczej $^{33}$. Kwestia ta ma szczególne znaczenie w przypadku prowadzenia działalności gospodarczej. W orzecznictwie wyraźnie podkreślany jest fakt, że ryzyko prowadzenia działalności gospodarczej spoczywa na podatniku jako przedsiębiorcy ${ }^{34}$. Organy podatkowe zobowiązane są do tego, by w każdym stanie faktycznym ustalając istnienie lub nie ważnego interesu podatnika, dokładnie badać to, czy podatnik dochował należytej staranności w swoim działaniu, czy też jego niedbalstwo doprowadziło go do utraty zdolności finansowych ${ }^{35}$. Trzecią grupę sytuacji wyczerpujących znamiona klauzuli generalnej stanowią obiektywne zdarzenia, które spowodowane są błędnym lub opieszałym działaniem organów podatkowych ${ }^{36}$. Czwarta grupa wartości, do których odsyła ważny interes podatnika, związana jest z tym, że klauzula ta stanowi również warunek udzielenia zwolnienia płatnika z obowiązku poboru podatku, jeżeli pobranie podatku zagraża ważnym interesom podatnika, a w szczególności jego egzystencji. Zwolnienia udziela organ podatkowy na wniosek podatnika ${ }^{37}$. W tym przypadku interpretacja klauzuli generalnej, jaką jest ważny interes podatnika, jest ustawowo ukierunkowana. Klauzula odsyła bowiem nie

32 Zob. wyrok NSA z dnia 10 marca 2009 r., I FSK 31/08, LEX nr 537191; wyrok NSA z dnia 28 kwietnia 2009 r., I FSK 263/08, LEX nr 513778; wyrok NSA z dnia 22 lipca 2009 r., II FSK 71/09, LEX nr 555537.

33 Por. wyrok NSA z dnia 10 marca 2010 r., I FSK 31/08, CBOSA; wyrok WSA w Warszawie z dnia 7 października 2010 r., CBOSA. W tym drugim wyroku sąd uznał, iż przy udzielaniu ulg podatkowych w spłacie podatku należy uwzględnić także stopień zawinienia podatnika.

34 Wyrok WSA w Warszawie z dnia 8 stycznia 2007 r., III SA/Wa 2904/2006, Monitor Podatkowy 2007, nr 11, s. 43-45.

35 Por. wyrok WSA w Łodzi z dnia 19 maja 2011 r., I SA/Łd 148/11, CBOSA; podobnie zob. wyrok WSA w Gliwicach z dnia 4 grudnia 2008 r., I SA/Gl 60/08, LEX nr 479767.

36 Zob. A. Gomułowicz, A. Skoczylas, Odraczanie terminów przewidzianych w przepisach prawa podatkowego (art. $48 \$ 1 i 2$ o.p.), w: A. Choduń, A. Gomułowicz, A. Skoczylas, Klauzule generalne i zwroty niedookreślone w prawie podatkowym i administracyjnymi. Wybrane zagadnienia teoretyczne $i$ orzecznicze, Warszawa 2013, s. 79 oraz orzecznictwo tam powołane: wyrok WSA we Wrocławiu z dnia 3 listopada 2010 r., I SA/Wr 611/10, CBOSA, podobnie wyrok NSA z dnia 22 lipca 2009 r., II FSK 71/09, LEX nr 555537; wyrok WSA w Szczecinie z dnia 3 września 2009 r., I SA/Sz 428/09, LEX nr 529225; wyrok WSA w Bydgoszczy z dnia 20 października 2004 r., I SA/Bd 420/04, LEX nr 800246; wyrok WSA we Wrocławiu z dnia 19 marca 2004 r., I SA/Wr 3478/01, LEX nr 680435. 
tylko do wymienionych wyżej grup wartości pozaprawnych, ale przede wszystkim nakazuje uwzględnienie przez organ podatkowy konkretnych ocen pozaprawnych powiązanych $\mathrm{z}$ ochroną egzystencji podatnika ${ }^{38}$. Zgodnie z orzecznictwem pojęcie „egzystencja” jest niedookreślony na gruncie ordynacji podatkowej i dlatego należy je interpretować zgodnie z jego definicją obowiązującą w przepisach ustawy o pomocy społecznej. Zgodnie z ich treścią wyrażenie „zagrożenie egzystencji danej osoby" oznacza obiektywnie trudne położenie materialne uprawniające do przyznania świadczeń ze środków pomocy społecznej ${ }^{39}$. Organ podatkowy zagrożenie ważnych interesów podatnika, a w szczególności nadzwyczajne zagrożenie podstaw jego egzystencji, ustala zatem, dokonując obiektywnej oceny sytuacji podatnika i jego ochrony przed utratą ekonomicznych podstaw utrzymania ${ }^{40}$. Zaznaczyć należy, że przesłanka dotycząca zagrożenia egzystencji podatnika w połączeniu z klauzulą generalną chroniącą ważny interes podatnika zastosowana została w ordynacji podatkowej tylko jeden raz, nie znalazła się ona bowiem w przepisach normujących udzielania ulg podatkowych w zapłacie podatku ${ }^{41}$. Rozwiązanie takie może świadczyć o tym, że ustawodawca stara się jak najrzadziej łączyć wyrażenia dotyczące najważniejszych wartości pozaprawnych, takich jak życie lub zdrowie człowieka $\mathrm{z}$ treścią klauzul generalnych ${ }^{42}$. Zasadniczym celem tego typu nieostrych zwrotów ocennych jest bowiem utworzenie względnie szerokiej płaszczyzny pozaprawnej dla uznania administracyjnego. Wprowadzenie do przepisów normujących klauzulę dodatkowego nieostrego wyrażenia, jakim jest „zagrożenie egzystencji podatnika”, automatycznie ów luz decyzyjny organu znacząco rozszerza. Organ podatkowy w przypadku powołania się podatnika na to, że zapłata podatku zagraża jego egzystencji, nie może się ograniczać do ogólnego badania warunków jego życia osobistego, rodzinnego oraz majątkowego. Zobowiązany jest także do zbadania i oceny wszelkich okoliczności związanych z zagrożeniem egzystencji podatnika, czyli jego zdrowia i życia.

38 Zob. uchwała SN z dnia 6 lutego 2002 r., III RN 201/00, Orzecznictwo Sądów Powszechnych 2004, nr 1, poz. 10; wyrok NSA z dnia 13 czerwca 2003 r., I SA/Łd 1194/02, CBOSA; A. Hanusz, Klauzule generalne $w$ ordynacji podatkowej..., s. 13 i orzecznictwo tam powołane: m.in. wyroki NSA z dnia 26 lipca 2011 r., II FSK 425/10, LEX nr 895907; wyrok NSA z dnia 19 sierpnia 2010 r., II FSK 619/09, LEX nr 745769.

39 Zob. wyrok NSA z dnia 12 marca 1999 r., I SA/Po 1233/98, Glosa 2002, nr 5, s. 21; wyrok NSA z dnia 3 października 2000 r., III SA 1801/99, niepublikowany, cyt. za: H. Dzwonkowski, J. Kondratowska Komentarz do art. 22, w: Ordynacja podatkowa. Komentarz, red. H. Dzwonkowski, Warszawa 2016, s. 272-280, 278.

40 Zob. wyrok NSA z dnia 24 kwietnia 2003 r., III SA 2512/01, Monitor Podatkowy 2003, nr 11, s. 37; wyrok WSA w Białymstoku z dnia 10 grudnia 2008 r., I SA/Bk 328/08, LEX nr 519211.

41 Przywołania zagrożenia egzystencji podatnika nie ma ani w art. $48 \$ 1$ o.p. ani w art. 67a o.p.

42 Por. R. Mastalski, Tworzenie prawa podatkowego a jego stosowanie, Warszawa 2012, s. 220. 
Klauzula generalna chroniąca interes jednostkowy unormowana jest także $\mathrm{w}$ ustawie o grach hazardowych i jest to ważny interes uczestnika gry ${ }^{43}$ lub interes uczestników gier hazardowych ${ }^{44}$, lub interes uczestników gry lub zakładu wzajemnego ${ }^{45}$ bądź też interesu finansowego uczestników gier hazardowych ${ }^{46}$. Wspólnym i zasadniczym celem wymienionych klauzul zawartych w ustawie o grach hazardowych jest ochrona interesów graczy przed uzależnieniem się od hazardu. Utrata kontroli nad uprawianiem hazardu charakteryzuje się brakiem odczuwalnych (somatycznych) objawów, które mogłyby pomóc w jego diagnozie. Patologiczny hazard został podniesiony do rangi osobnego zaburzenia psychicznego. Z uwagi na owo zagrożenie uzależnieniem uczestników różnego typu gier hazardowych niezbędna jest konieczność kontroli tego typu działalności gospodarczej ze strony państwa w postaci reglamentacji prawnej, której przestrzeganie powierzone jest wyspecjalizowanym organom ${ }^{47}$.

\section{Generalne klauzule antyabuzywne}

W przepisach prawa podatkowego obecnie są unormowane dwie klauzule antyabuzywne, a mianowicie w ordynacji podatkowej klauzula przeciwko unikaniu opodatkowania ${ }^{48}$ oraz tzw. mała klauzula przeciwko unikaniu opodatkowania w ustawie o podatku dochodowym od osób prawnych ${ }^{49}$.

Głównym celem klauzul antyabuzywnych jest jednoczesna ochrona budżetu państwa i rzetelnych podatników przed nieuczciwymi podatnikami i kontrahentami

43 Art. 23d u.g.h.

44 Zob. art. 21 ust. 3 u.g.h.

45 Zob. art. 22 ust. 4 u.g.h.

46 Zob. art. 63 ust. 1 oraz art. 67 u.g.h.

47 Zob. L. Wilk, Karnoprawne aspekty ustawy o grach hazardowych, Przegląd Sądowy 2010, nr 11-12, s. 7-8; uzasadnienie z dnia 12 listopada 2009 r. projektu ustawy o grach hazardowych, Druk sejmowy nr 2481 Sejmu RP VI kadencji.

48 Zob. art. 119a-119f. Przepisy o charakterze antyabuzywnym występują w wielu krajach. Przykłady rozwiązań obowiązujących w państwach europejskich zob. J.M. Mössner, Tax avoidance concepts and European tax education, European Taxation 1999, t. 39, nr 3, s. 92-135.

49 Zob. art. 22c ustawy z dnia z dnia 15 lutego 1992 r. o podatku dochodowym od osób prawnych, tekst jednolity: Dz. U. z 2020 r. poz. 1406 z późn. zm. (dalej: u.p.d.o.p.). Artykuł ten obowiązuje od dnia 1 stycznia 2016 r. Przepis ten został wprowadzony w celu implementacji art. 4 i 5 dyrektywy 2011/96/ UE z dnia 30 listopada 2011 r. sprawie wspólnego systemu opodatkowania mającego zastosowanie w przypadku spółek dominujących i spółek zależnych różnych państw członkowskich (Dz. Urz. UE L 345 z 29.12.2011). Celem przepisów jest zapobieganie ryzyku wystąpienia podwójnego nieopodatkowania zysków z dywidend w sensie ekonomicznym prawnym. 
posługującymi się sztucznymi konstrukcjami ekonomicznymi w celu uniknięcia podatku. Analiza polskich rozwiązań ani tych w wersji pierwotnej, ani zmienionej nie potwierdza takiego kierunku interpretacji przepisów ordynacji podatkowej.

Najogólniej mówiąc, obowiązująca obecnie klauzula generalna, zgodnie ze swoją nazwą i treścią, wymierzona jest w negatywne zjawisko polegające na unikaniu opodatkowania przez podmioty do tego zobowiązane ${ }^{50}$. Klauzula powinna stanowić instrument wspierający realizację konstytucyjnej zasady równości opodatkowania nie tylko na płaszczyźnie stanowienia, ale także stosowania prawa. Podatnik unikający opodatkowania pod względem finansowym znajduje się bowiem w korzystniejszej sytuacji niż ten, który także podejmuje aktywność w sferze gospodarczej czy finansowej, lecz nie obniża w sztuczny sposób poziomu swoich obciążeń podatkowych. Problem ten jest tym bardziej ważki, że konstruowanie i wdrażanie tzw. sztucznych konstrukcji prawnych zmierzających do unikania opodatkowania wymaga posiadania zasobów finansowych i dzięki temu dostępu do wysoko wykwalifikowanej obsługi prawnej. Co oznacza, że po konstrukcje te z reguły sięgają duże podmioty gospodarcze, często powiązane kapitałowo i zarządczo z podmiotami zagranicznymi. Unikanie opodatkowania jest zatem niezmiernie groźne, gdyż narusza konstytucyjną zasadę ochrony reguł konkurencji w sferze gospodarczej ${ }^{51}$. Klauzula przeciwko unikaniu opodatkowania spełnia także funkcję prewencyjną. Stosowana bowiem nawet $\mathrm{w}$ umiarkowanej skali, $\mathrm{z}$ uwagi na sam fakt jej obowiązywania, może zniechęcać podatników do działań zmierzających do unikania opodatkowania. W ten sposób klauzula może też wpływać na adekwatność opodatkowania, co z kolei wiąże się z następną jej funkcją polegającą na zapewnieniu stabilności finansów publicznych ${ }^{52}$. Klauzula może więc przyczynić się do uporządkowania systemu prawa podatkowego poprzez wyznaczenie granic dopuszczalnej

50 Polskie wyrażenie „unikanie opodatkowania” jest kalką językową sformułowania angielskiego „tax avoidance". Szerzej na temat samego wyrażenia oraz zjawiska unikania opodatkowania stanowiącego jedną z form ucieczki od podatków, zob. P. Merks, Tax evasion. Tax avoidance and Tax Planning, INTERTAX 2006, t. 34, z. 5, s. 272-276; M. Kalinowski, Granice legalności unikania opodatkowania w polskim systemie podatkowym, Toruń 2001, s. 15-28; P. Karwat Obejście prawa podatkowego, Warszawa 2003, s. 18-28; A. Olesińska, Klauzula ogólna przeciwko unikaniu opodatkowania, Toruń 2013, s. 26-30. Szerokie spektrum schematów, które mogą prowadzić do unikania opodatkowania, zob. Uzasadnienie wprowadzenia do ordynacji podatkowej klauzuli przeciwko unikaniu opodatkowania, http://legislacja.rcl.gov.pl/docs/2/12280401/12330297/12330298/dokument203501.pdf [dostęp: 4.11.2020 r.].

51 Zob. art. 22 Konstytucji RP. Zob. także: J. Ciapała Konstytucyjna zasada wolności działalności gospodarczej, Ruch Prawniczy Ekonomiczny i Socjologiczny 2001, z. 4, s. 29; R. Mastalski, Tworzenie prawa podatkowego..., s. 161.

52 B. Brzeziński, Wykładnia prawa podatkowego, Gdańsk 2013, s. 168; R. Mastalski, Tworzenie prawa podatkowego..., s. 158. 
optymalizacji podatkowej oraz wzmocnienie autonomii prawa podatkowego wobec prawa cywilnego ${ }^{53}$.

Wszystkie te założenia i postulaty związane z istotą klauzuli generalnej antyabuzywnej pozostają jedynie sferą założeń i idei. Wprowadzona do ordynacji podatkowej tzw. duża klauzula przeciwko unikaniu opodatkowania jest obecnie w zasadzie martwą instytucją. Główną przyczyną takiego stanu rzeczy jest jej niezwykle rozbudowana konstrukcja normatywna, w której występują liczne sformułowania ekonomiczne, takie jak: sztuczny sposób działania, działanie rozsądne, a także uzasadnienie ekonomiczne lub gospodarcze oraz ryzyko ekonomiczne lub gospodarcze.

Druga antyabuzywna klauzula generalna unormowana jest w przepisach ustawy o podatku dochodowym od osób prawnych dotyczących opodatkowania dochodów zagranicznej spółki kontrolowanej controlled foreign corporations (companies) (dalej: CFC $)^{54}$. Celem tej klauzuli jest wyeliminowanie fikcyjnych uzgodnień, które nie odzwierciedlają rzeczywistości gospodarczej i służą głównie uzyskaniu korzyści podatkowej, nieuzasadnionej z punktu widzenia istoty dyrektywy Rady UE ${ }^{55}$. Przyjęte regulacje są krytykowane w polskim piśmiennictwie $\mathrm{z}$ uwagi na to, że pozwalają one na opodatkowanie u podatnika mającego udziały w zagranicznej spółce kontrolowanej dochodów tej spółki.

W świetle przyjętych rozwiązań dochody osiągnięte przez spółkę za granicą są co do zasady przedmiotem polskiego podatku dochodowego u jej udziałowca ${ }^{56}$. Jednakże $\mathrm{w}$ niektórych sytuacjach ustawodawca wyłącza zastosowanie wobec podatników niektórych albo wszystkich przepisów dotyczących opodatkowania w Polsce dochodów osiągniętych za granicą przez zagraniczne spółki kontrolowane przez podatnika. Powody wyłączenia stosowania tych przepisów generalnie są dwojakiego rodzaju. Pierwszy związany jest $\mathrm{z}$ wysokością rocznych przychodów zagranicznej spółki kontrolowanej, drugi - z faktem prowadzenia przez zagraniczną spółkę kontrolowaną rzeczywistej działalności gospodarczej.

53 Uzasadnienie wprowadzenia do ordynacji podatkowej klauzuli przeciwko unikaniu opodatkowania, http://legislacja.rcl.gov.pl/docs/2/12280401/12330297/12330298/dokument203501.pdf [dostęp: 4.11.2016 r.].

54 Zob. art. 30 ust. 20 pkt 2 u.p.d.o.f. i art. 24a u.p.d.o.p. Szerzej na temat wszystkich klauzul szczegółowych oraz innych regulacji zapobiegających unikaniu opodatkowania zob. P. Karwat, Klauzula ogólna a przepisy szczególne przeciwdziałające unikaniu opodatkowania, Przegląd Podatkowy 2016, nr 12, s. $12-20$.

55 Zob. dyrektywa Rady 2011/96/UE z dnia 30 listopada 2011 r. w sprawie wspólnego systemu opodatkowania mającego zastosowanie w przypadku spółek dominujących i spółek zależnych różnych państw członkowskich, Dz. Urz. UE L 345/8 z 29.12.2011.

56 A. Bartosiewicz, R. Kubacki, Komentarz do art. 30(f) ustawy o podatku dochodowym od osób fizycznych, 2015 [baza danych LEX]. 


\section{Zakończenie}

Funkcjonujące w przepisach prawa podatkowego klauzule generalne odsyłają do różnego rodzaju kryteriów pozaprawnych należących do różnych wartości mieszczących się w ramach aksjologii zewnętrznej. Analiza piśmiennictwa i względnie jednolitego orzecznictwa wskazuje na to, że w przypadku klauzul generalnych chroniących interes publiczny interpretatorzy z reguły utożsamiają go bezpośrednio lub pośrednio $\mathrm{z}$ bezpieczeństwem finansowym, ekonomicznym lub gospodarczym podmiotu prawa publicznego. Natomiast w przypadku klauzul generalnych chroniących ważny interes jednostki reguły wykładni funkcjonalnej prowadzą do takich kryteriów aksjologii zewnętrznej jak życie lub zdrowie podatnika i jego rodziny czy też bezpieczeństwo gospodarcze przedsiębiorcy naruszone zdarzeniami spowodowanymi vis maior. Obydwa rodzaje klauzul szczególnego znaczenia nabierają na gruncie tych przepisów, w których występują razem. W tych przypadkach podmioty dokonujące operatywnej wykładni prawa zobligowane są bowiem do tego, by w toku doprecyzowywania zakresu znaczeniowego interesu publicznego i ważnego interesu podatnika obydwa dobra traktować równorzędnie.

Nieco inaczej wygląda obszar wartości aksjologicznych w przypadku tych klauzul generalnych, które łączą ochronę interesu publicznego z zapewnieniem państwu bezpieczeństwa (ekonomicznego, ekologicznego) oraz porządku publicznego. Wykładnia funkcjonalna tych zwrotów ocennych wydaje się uproszczona, gdyż ich jednoznaczna treść normatywna wskazuje kierunkowe pozaprawne kryteria interpretacyjne, takie jak: bezpieczeństwo publiczne i paliwowe państwa, ochrona środowiska, dobrostan ekonomiczny lub finansowy Rzeczypospolitej Polskiej lub Unii Europejskiej.

Zdecydowanie trudniej jest wskazać właściwe obszary aksjologiczne w przypadku polskich regulacji dotyczących antyabuzywnych klauzul generalnych, czyli dużej i małej klauzuli przeciwko unikaniu opodatkowania. Problemy interpretacyjne dotyczące tych zwrotów nieostrych są pokłosiem po pierwsze bardzo skomplikowanych redakcji językowych obydwóch klauzul, po wtóre braku jasnych wytycznych dotyczących ich interpretacji ze strony ustawodawcy. Dodatkowym problemem związanym z wyznaczeniem kryteriów aksjologicznych właściwych dla wykładni tych klauzul jest brak orzecznictwa sądowego. Z tych względów obszar pozaprawny, do którego należy sięgać w celu dookreślenia ich zakresu znaczeniowego, wyznacza w zasadzie piśmiennictwo. Jego analiza wskazuje na dychotomiczność tych klauzul. Z reguły przyjmuje się bowiem, że zwroty te powinny chronić jednocześnie interes fiskalny państwa oraz pozycję gospodarczą podatnika. 
Reasumując, stwierdzić należy, że unormowane w przepisach prawa podatkowego różnego rodzaju klauzule generalne niezależnie od ich rodzajów oscylują wokół ochrony dwóch generalnych różnych dóbr: publicznego i jednostkowego.

\section{Bibliografia}

Bartosiewicz A., Kubacki R., Komentarz do art. 30(f) ustawy o podatku dochodowym od osób fizycznych, 2015 [baza danych LEX].

Borkowski J., Komentarz do art. 253, w: B. Adamiak, J. Borkowski, R. Mastalski, J. Zubrzycki, Ordynacja podatkowa. Komentarz 2012, Wrocław 2012.

Borszowski P., Określenia nieostre i klauzule generalne w prawie podatkowym, Warszawa 2017.

Borszowski P., Ważny interes podatnika $w$ regulacji ulg $w$ spłacie zobowiązań podatkowych, LEX nr 180045.

Brolik J., Komentarz do art. 253, w: J. Brolik i in., Ordynacja podatkowa. Komentarz, 2013 [baza danych LEX].

Brzeziński B., Wykładnia prawa podatkowego, Gdańsk 2013.

Ciapała J., Konstytucyjna zasada wolności działalności gospodarczej, Ruch Prawniczy Ekonomiczny i Socjologiczny 2001, z. 4.

Dauter B., Komentarz do art. 67, w: S. Babiarz i in., Ordynacja podatkowa. Komentarz, Warszawa 2009.

Dzwonkowski H., Kondratowska J., Komentarz do art. 22, w: Ordynacja podatkowa. Komentarz, red. H. Dzwonkowski, Warszawa 2012.

Gomułowicz A., Skoczylas A., Odraczanie terminów przewidzianych w przepisach prawa podatkowego (art. $48 \$ 1$ i2 o.p.), w: A. Choduń, A. Gomułowicz, A. Skoczylas, Klauzule generalne $i$ zwroty niedookreślone $w$ prawie podatkowym $i$ administracyjnymi. Wybrane zagadnienia teoretyczne i orzecznicze, Warszawa 2013.

Gruszczyński B., Komentarz do art. 22, w: S. Babiarz i in., Ordynacja podatkowa. Komentarz, Warszawa 2009.

Grzybowski S., Struktura i treść przepisów prawa cywilnego odsyłających do zasad współżycia społecznego, Studia Cywilistyczne 1965, t. 6.

Hanusz A., Klauzule generalne w ordynacji podatkowej, Państwo i Prawo 2016, nr 8.

Kalinowski M., Granice legalności unikania opodatkowania w polskim systemie podatkowym, Toruń 2001.

Karwat P., Obejście prawa podatkowego, Warszawa 2003.

Karwat P., Klauzula ogólna a przepisy szczególne przeciwdziałające unikaniu opodatkowania, Przegląd Podatkowy 2016, nr 12.

Kordela M., Aksjologiczna wykładnia prawa, Acta Universitatis Wratislaviensis. Przegląd Prawa i Administracji 2017, t. 110.

Leszczyński L., Właściwości posługiwania się klauzulami generalnymi w prawie polskim. Perspektywa zmian trendu, Kwartalnik Prawa Prywatnego 1995, z. 3. 
Mastalski R., Tworzenie prawa podatkowego a jego stosowanie, Warszawa 2016.

Merks P., Tax evasion. Tax avoidance and Tax Planning, INTERTAX 2006, t. 34, z. 5.

Mössner J.M., Tax avoidance concepts and European tax education, European Taxation 1999, t. 39 , nr 3 .

Münnich M., Nieostre zwroty ocenne w polskim prawie podatkowym, Lublin 2017.

Olesińska A., Klauzula ogólna przeciwko unikaniu opodatkowania, Toruń 2013.

Safjan M., Klauzule generalne w prawie cywilnym. Przyczynek do dyskusji, Państwo i Prawo 1990, nr 11.

Stelmachowski A., Wstęp do teorii prawa cywilnego, Warszawa 1969.

Szczupakowski J., Kontrowersje wokół „wyważenia” ważnego interesu podatnika z interesem publicznym, w: Stanowienie stosowanie prawa podatkowego w Polsce. Ocena i kierunki zmian, red. B. Kucia-Guściora, M. Münnich, A. Zdunek, R. Zieliński, Lublin 2017.

Wilejczyk M., Integralna filozofia prawa Ronalda Dworkina a problem klauzul generalnych. Klauzule generalne jako odesłania wewnątrz systemowe, Państwo i Prawo 2019, nr 2.

Wilk L., Karnoprawne aspekty ustawy o grach hazardowych, Przegląd Sądowy 2010, nr 11-12.

Wójcik K., Z problematyki klauzul generalnych prawa cywilnego, Studia Prawno-Ekonomiczne 1982, t. 27.

Zasada proporcjonalności ( $w$ odniesieniu do prawa publicznego) w tezach Trybunału Konstytucyjnego, Biuro Trybunału Konstytucyjnego Zespół Orzecznictwa i Studiów, Warszawa 2009, http://trybunal.gov.pl/fileadmin/content/dokumenty/Zestawienie _tez_dotyczacych_zasady_proporcjonalnosci_w_zakresie_pawa_publicznego.pdf [dostęp: 5.12.2020 r.].

Zenc R., „Ważny interes podatnika” przy udzielaniu ulg $w$ spłacie zobowiązań podatkowych, Prawo Pomocy Publicznej 2014, nr 4. 